Bull. Fac. Agric, Cairo Univ., 69:211-222 (2018)

\title{
EFFECT OF SOME CHEMICAL COMPOUNDS AND BIOCIDES ON Cercospora LEAF SPOT DISEASE OF SUGAR BEET
}

(Received: 29.7.2018)

\author{
By \\ A. M. El- Shazly, Y.A. Arab, Manal Y. Hussien * and M. S. Abbas* \\ Department of Agricultural Botany, Faculty of Agriculture, Al -Azhar University Cairo \\ * Department of Plant Pathology, Sugar Crops Research Institute, Agricultural Research Center, Giza
}

\begin{abstract}
Cercospora leaf spot of sugar beet plants (Beta vulgaris L.) caused by Cercospora beticola Sacc. is one of the most serious foliar disease of sugar beet worldwide. Efficacy of five chemical compounds, i.e. Boric acid, Zink sulphate, Calcium chelate, Potassium bicarbonate and Salicylic acid, two biocides (Bio ARC and Blite stop) and score fungicide beside untreated treatment (control) were tested in the fields of two locations, New Nubariya County and Kafr El-Sheikh County under natural infection. Three spraying programs were utilized. For the first program, plants were sprayed twice, at 60 and 90 days after planting. In the second program, plants were sprayed twice, at 90 and at 120 days after planting, while plants of the third program were sprayed three times at 60,90 and at 120 days after planting. The results showed that all the tested materials exhibited a different degree at efficiency for the disease severity percentage and sucrose percentage, extractability percentage, root yield and sugar yield in comparison with the control treatment. Score fungicide gave the best results compared to all the tested materials ، biocide Bio-ARC recorded disease severity (8.58\%) followed by Blite stop (as a new Egyptian commercial bio-product) (12.27\%). Salicylic acid was the best tested chemical inducer (9.36\%) followed by Potassium bicarbonate (10.35\%); Calcium chelate (11.43\%); Boric acid (13.56\%) and Zink sulphate (16.62\%) as compared with (23.4\%) for control treatment. Spraying at 60,90 and 120 days after planting gave the best results of all the measurements, where sugar yield recorded (2.97 ton/fed) while the spraying at 90 and 120 days gave (2.47 ton/fed). New Nubariya plants were the best of the disease tolerance, root yield and sugar yield while sucrose (\%) and extractability (\%) was not affected by the location. We found an increase of leaf content of free, conjugated and total phenols as a result of spraying with the chemical compounds and the biocides, also we found an increase in the activity of peroxidase and polyphenoloxidase.
\end{abstract}

Key Words: Sugar beet (Beta vulgaris L.), Cercospora leaf spot disease, Cercospora beticola, plant resistance inducers.

\section{INTRODUCTION}

Sugar beet (Beta vulgaris L.) is one of the most important crops grown for sugar production in temperate regions. In Egypt, it ranked second after sugar cane for sugar production (Eweis et al., 2006). Cercospora beticola is the causative agent of Cercospora leaf spot disease (Felipini et al., 2015; and El-Sayed and El-Sherbeni, 2017). Cercospora leaf spot infection can cause severe yield loss in sugar beet susceptible varieties ranging from $10-50 \%$ in Australia, and from 15$40 \%$ in France (Kaiser and Varrelmann, 2009).
There are many products composed of living organisms, primarily bacteria and fungi, that increase plant health (Bloom et al., 2003).

Some chemical compounds enhance the defense system in the plant against diseases, e.g. Salicylic acid has been shown to induce resistance in plants (Mandal et al., 2009). This could be due to the increase of phenols and activation of many enzymes such as polyphenoloxidase and peroxidase (Hussein, 2011; Abd El-Al et al., 2012). The role of calcium in reducing disease disorders is mentioned by Conway et al. (1992). 
The mechanism of calcium salts in reducing disease severity percentage depends on the $\mathrm{Ca}^{+2}$ status of the membrane (Xing et al., 1996). Boron has a direct function in cell wall structure and stability and has a beneficial effect on reducing disease severity. However, in several diseases, the function of boron in disease resistance or tolerance is the least understood of all the essential micronutrients in plants (Blevins and Lukaszewski, 1998). The relationship between boron and sugar beet infection percentage with cucumber mosaic virus (CMV) was reported by Awad (2005). He found that the infection percentage with CMV decreased in sugar beet plants treated with boron in addition to decreasing the effect of CMV on leaf content of chlorophyll and root content of total carbohydrates and sucrose. Plant spraying with potassium bicarbonate solution provided an effective protection against some diseases (Smilanick et al., 2006). It could be suggested that using potassium bicarbonate may be useful for controlling sugar beet leaf spot disease under field conditions (Hussien et al., 2009). Zink element is involved in membrane protection against oxidative damage through the detoxification of superoxide radicals (Cakmak, 2000).

The traditional means to control this destructive disease is applying harmful fungicide. However, using biological agents is encouraged at the time being. Many of previous investigations succeeded in reducing infection with leaf spot diseases of different crops by using some bioagents (ElAssiuty et al., 2009).

The main objective of the present research was studying the effect of some chemical compounds and biocides against Cercospora leaf spot disease on sugar beet caused by Cercospora beticola.

\section{MATERIALS AND METHODS}

In the current trial, some control materials were tested for their potentialities to decrease the disease severity percentage under field conditions at two Egyptian locations of sugar beet cultivation (New Nubariya County, Beheira Governorate and Kafr El-Sheikh County, Kafr El-Sheikh Governorate) during 2015-2016 season using three spraying programs. During the present study, application of the control materials Table (1) was carried through 3 spraying programs depending on plant age: In the first, sugar beet plants were sprayed twice, i.e. at 60 and at 90 days after planting; for the second, plants were sprayed twice with the tested materials at 90 and 120 days after planting and for the third program, plants were sprayed three times at 60,90 and 120 days after planting. The following data were recorded:

1- Disease severity (\%) was estimated according to

Shane and Teng (1992), after 30 days from the last spray in each program.

2- Root yield (ton/fed).

3- Sugar yield (ton/fed).

4- Sucrose percentage which was estimated using the method adopted by Le- Docte (1927).

5- Extractability percentage $=$ Sugar extraction $(\%) /$ sucrose $(\%)$

where sugar extraction $(\%)=$ Sucrose $(\%)-$ Sugar loss to molasses (\%) - 0.6 according to Dexter et al. (1967).

6 - Phenolic content:

Phenolic components were determined in the ethanolic extraction of sugar beet leaves using Folin-Ciocalteu's reagent described by Bray and Thrope, (1954). The ethanolic extracts of sugar beet leaves were made by shaking $100 \mathrm{ml}$ ethanol containing $5 \mathrm{~g}$ sugar beet leaves for 24 hours and then left at the room temperature until ethanol evaporates, then completed to $100 \mathrm{ml}$ with distilled water.

To determine the free phenols $(\mathrm{mg} / \mathrm{g}$ fresh weight), $1 \mathrm{ml}$ of the ethanolic extract was mixed with $1 \mathrm{mI}$ of Folin-Ciocatalteu's reagent and $1 \mathrm{ml}$ sodium carbonate $(14 \%)$. The reaction mixture was completed to $5 \mathrm{ml}$ with distilled water, thoroughly mixed, heated in a boiling water bath for $10 \mathrm{~min}$., then cooled and the developing colour was measured at $650 \mathrm{~nm}$ against reagent blank using the Spectrophotometer. A standard curve from caticol was used to calculate the amount of phenols in different samples.

To determine the total phenols $(\mathrm{mg} / \mathrm{g}$ fresh weight), $1 \mathrm{ml}$ of the ethanolic extract was mixed with $0.5 \mathrm{mI}$ of Folin-Ciocatalteu's reagent and incubated at room temperature for 3 minutes, then $2 \mathrm{ml}$ of $20 \%$ sodium carbonate were added, mixed well and incubated in boiling water bath for 1 minute then cooled rapidly and read absorbance at $650 \mathrm{~nm}$ against reagent blank using the Spectrophotometer. A standard curve from caticol was used to calculate the amount of phenols in different samples. 
The conjugated phenols (mg/g fresh weight) were calculated by subtracting free phenols from the total phenols.

Standard curve from caticol was prepared by making different concentrations of caticol and read each of them at $650 \mathrm{~nm}$ using the Spectrophotometer and then using microsoft office excel program to elicitation linear relationship.

7 - Activities of antioxidant enzymes:

Fresh leaf samples were grind in a mortar with $0.1 \mathrm{M}$ sodium phosphate buffer $(\mathrm{pH} 7.1)$ at rate (2 $\mathrm{ml}$ buffer/ $1 \mathrm{~g}$ fresh leaf) according to (Goldschmidt et al., 1968). The mixture was filtrated through several layers of cheesecloth, then centrifuged at $1500 \mathrm{rpm}$ for $20 \mathrm{~min}$. at $6^{\circ} \mathrm{C}$. The obtained supernatant fluids were used for determination the activities of oxidative enzymes b - Peroxidase assay: Determination of peroxidase activity was based on oxidation of pyrogallol to purpurogallin in the presence of $\mathrm{H}_{2} \mathrm{O}_{2}$ according to the method described by Allam and Hollis (1972). The reaction mixture contained $0.5 \mathrm{ml}$ of $0.1 \mathrm{M}$ sodium phosphate buffer at $\mathrm{pH} 7,0.3$ $\mathrm{ml}$ of enzyme extract, $0.3 \mathrm{ml}$ of $0.05 \mathrm{M}$ pyrogallol, $0.1 \mathrm{ml}$ of $1.0 \% \mathrm{H}_{2} \mathrm{O}_{2}$ and completed with distilled water to $3.0 \mathrm{ml}$. The activity of peroxidase was expressed as the change in absorbency per 1 minute for 10 minute procedures at $425 \mathrm{~nm}$ wave length.

Statistical analysis: The collected data were statistically analyzed according to the method described by Snedecor and Cochran (1981). The collected data were subjected to the proper statistical analysis of Complete Block Design Combined over Locations.

Table (1): Control materials tested against Cercospora leaf spot disease of sugar beet grown in New Nubariya County and Kafr El-Sheikh County.

\begin{tabular}{|c|c|c|c|}
\hline Locations & Spraying program & \multicolumn{2}{|c|}{ Control materials, concentrations } \\
\hline \multirow{3}{*}{ Kafr El Sheikh county } & \multirow{3}{*}{$\begin{array}{l}\text { The first program: } \\
\text { Two times, at } 60 \text { and at } 90 \\
\text { days after planting } \\
\text { The second program: } \\
\text { Two times, at } 90 \text { and } 120 \\
\text { days after planting } \\
\text { The third program: } \\
\text { Three times, at } 60 \text {, at } 90 \text { and } \\
\text { at } 120 \text { days after planting }\end{array}$} & $\begin{array}{l}\text { Chemical } \\
\text { compound }\end{array}$ & $\begin{array}{lc}\text { Boric acid } & 1 \mathrm{~g} / \mathrm{l} \\
\text { Zink sulphate } & 5 \mathrm{~g} / 1 \\
\text { Calcium chelate } & 6 \mathrm{~g} / 1 \\
\text { Potassium bicarbonate } 2 \mathrm{~g} / 1 \\
\text { Salicylic acid } & 4 \mathrm{~g} / 1\end{array}$ \\
\hline & & Biocide & $\begin{array}{l}\text { Bio ARC( Bacillus megaterium) } 2.5 \\
\text { g/l } \\
\text { Blite stop* (Trichoderma harzianum } \\
+ \text { B. subtilis) } 6.6 \mathrm{ml} / 1\end{array}$ \\
\hline & & Fungicide & Score $250 \mathrm{EC}$ \\
\hline
\end{tabular}

* New Egyptian commercial bio-product.

(polyphenoloxidase and peroxidase) as follows:

a - Polyphenoloxidase assay: Polyphenoloxidase was determined according to (Malta and Dimond, 1963). The reaction mixture contained $1.0 \mathrm{ml}$ of enzyme extract, $1.0 \mathrm{ml}$ of $0.2 \mathrm{M}$ sodium phosphate buffer at $\mathrm{pH} 7,1.0 \mathrm{ml}$ of $10^{-3} \mathrm{M}$ catechol and completed with distilled water to $6.0 \mathrm{ml}$. The activity of polyphenoloxidase was expressed as the change in absorbence per 30 second for 5 minute procedures at $495 \mathrm{~nm}$ wave length.

\section{RESULTS AND DISCUSSION}

The data illustrated in Table (2) show that all control materials used significantly decreased the disease severity (\%) compared with the control treatment. Score treatment gave the highest decrease where disease severity recorded $2.73 \%$ followed by Bio-ARC $8.58 \%$, then Salicylic acid 9.36\% while Zink sulphate exhibited the lowest decrease $16.62 \%$ followed by Boric acid $13.56 \%$, then Blite stop $12.27 \%$. Spraying the plants at 60,90 and 120 days after planting achieved the 
highest decrease where disease severity recorded $10.59 \%$ while spraying at 90 and 120 days decreased the disease severity to $13.92 \%$. With respect to locations, New Nubariya was the best where disease severity recorded $10.2 \%$ compared with Kafr El-Sheihk which recorded 13.8\%. This result is in agreement with those reported by Jung and Kim (2005) and Kildea et al. (2008) who reported that Bacillus megaterium (the active organism of Bio- ARC) showed potential for the biocontrol of Rhizoctonia-root rot of soybean, Phytophthora-blight of red-pepper and Septoria blotch of wheat. Many Bacillus species have provn to be effective against a broad range of plant pathogens (Kumar et al., 2011 and Shafi et al., 2017). Also, Galletti et al. (2008) reported that indepth screening among different Trichoderma isolates can lead to the selection of isolates effective in increasing the defensive response of sugar beet plants to $C$. beticola under field conditions. The mechanism seems to be linked more to induce resistance than to direct competition. Many researchers reported that chemical inducers of plant resistance possess quite different modes of action as compared to synthetic biocides as they have no direct toxicity to pathogens, plants and animals; no negative effects on plant growth, development and yield, broad spectrum of defence, low loading amount, long lasting protection, low economical cost for farmers and good profit for producers (Ganesan and Thomas, 2001; Li and Zhang, 2012 and Takatsuji, 2014). This result also is in agreement with the findings of (Hussien, 2006) who pointed a significant reduction of Cercospora leaf spot disease severity on sugar beet treated with by Salicylic acid. Also, Banerjee et al. (2010) reported the induction of plant defense using chemical inducers results in increased ability of the plant to reinforce the plant cell wall by altering its composition, primarily with lignins, pectins, amide I structure, and lipids. Also, Hussien (2010) and Hussein (2011) reported that disease severity of sugar beet Cercospora leaf spot was reduced by application of potassium bicarbonate. Regarding boron action in reducing disease susceptibility, Brown et al. (2002) stated that this function may be due to: (1) its function in cell wall structure, (2) its function in cell membrane permeability, stability. In respect of calcium compounds action in reducing disease susceptibility, El-Kholi and Esh (2011) mentioned that Cercospora leaf spot severity on sugar beet plants treated with the two tested calcium compounds (calcium chelate and

Table (2): Effect of spraying some control materials on disease severity (\%) of Cercospora leaf spot on Sugar beet in fields at two locations, 2015/2016 growing season.

\begin{tabular}{|c|c|c|c|c|c|c|c|c|c|c|c|c|}
\hline & \multicolumn{3}{|c|}{ New Nubariya } & \multirow[b]{2}{*}{ Mean } & \multicolumn{3}{|c|}{ Kafr El-Sheikh } & \multirow[b]{2}{*}{ Mean } & \multicolumn{3}{|c|}{ Overall mean } & \multirow[b]{2}{*}{ Mean } \\
\hline & \&̊ & $\frac{\text { ฮิ }}{\text { ஓ̆ }}$ & 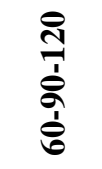 & & \&̊ & 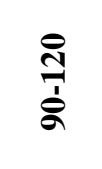 & 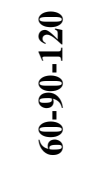 & & ڤ̊̀ & $\frac{\text { తి }}{\text { ஓ̊ }}$ & 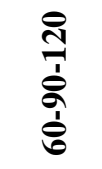 & \\
\hline Boric acid & 10.74 & 13.65 & 10.11 & 11.49 & 14.31 & 17.70 & 14.79 & 15.60 & 12.51 & 15.69 & 12.45 & 13.56 \\
\hline Zink sulphate & 12.81 & 14.55 & 12.24 & 13.20 & 17.70 & 26.91 & 15.60 & 20.07 & 15.24 & 20.73 & 13.92 & 16.62 \\
\hline Calcium chelate & 9.57 & 10.80 & 8.16 & 9.51 & 12.54 & 14.85 & 12.60 & 13.32 & 11.07 & 12.84 & 10.38 & 11.43 \\
\hline $\begin{array}{c}\text { Potassium } \\
\text { bicarbonate }\end{array}$ & 8.88 & 10.14 & 7.44 & 8.82 & 11.85 & 12.60 & 11.19 & 11.88 & 10.35 & 11.37 & 9.33 & 10.35 \\
\hline Salicylic acid & 7.71 & 9.24 & 7.14 & 8.04 & 10.86 & 11.01 & 10.29 & 10.71 & 9.30 & 10.14 & 8.70 & 9.36 \\
\hline Bio- ARC & 6.63 & 8.85 & 6.75 & 7.41 & 10.11 & 10.05 & 9.21 & 9.78 & 8.37 & 9.45 & 7.98 & 8.58 \\
\hline Blite stop & 10.44 & 11.85 & 9.24 & 10.50 & 13.35 & 15.30 & 13.38 & 14.01 & 11.91 & 13.59 & 11.31 & 12.27 \\
\hline Score & 1.23 & 2.28 & 1.20 & 1.56 & 3.51 & 3.75 & 4.41 & 3.87 & 2.37 & 3.00 & 2.82 & 2.73 \\
\hline $\begin{array}{c}\text { Control } \\
\text { (untreated) }\end{array}$ & 20.34 & 27.30 & 15.90 & 21.18 & 23.91 & 29.61 & 21.15 & 24.87 & 22.14 & 28.44 & 18.54 & 23.04 \\
\hline Mean & 9.81 & 12.09 & 8.67 & 10.20 & 13.11 & 15.75 & 12.51 & 13.80 & 11.46 & 13.92 & 10.59 & \\
\hline
\end{tabular}

$(\mathbf{L} \times \mathbf{S})=$ n.s

$(\mathbf{L} \times \mathbf{C})=\mathbf{n . s}$

$(\mathrm{S} \times \mathrm{C})=\mathbf{1 . 1 3}$

$(\mathrm{L} \times \mathrm{S} \times \mathrm{C})=\mathbf{n . s}$ 
calcium chloride) was significantly decreased as compared to untreated plants.

The data illustrated in Table (3) show that all control materials significantly increased the root yield compared with the untreated control. Score treatment showed the highest increase where root yield recorded 23.53 ton/fed followed by Bio ARC 20.95 ton/fed, then Salicylic acid 19.22 ton/fed and potassium bicarbonate 18.33 ton/fed while Zink sulphate showed the lowest increase where root yield recorded 14.37 ton/fed. Other treatments, i.e. Boric acid gave 15.38 ton/fed and Blite stop 16.46 ton/fed. Spraying at 60, 90 and 120 days after planting achieved the highest increase where root yield recorded 18.59 ton/fed while spraying at 90 and 120 days gave the lowest increase where root yield recorded 16.41 ton/fed. With respect to locations, New Nubariya was the best where root yield recorded 18.21 ton/fed compared with Kafr El-Sheikh which correlates between disease severity (\%) and root yield:0.633 recorded 17.02 ton/fed. It is worth mentioning that the correlation between disease severity and root yield was medium negative which recorded (-0.633). Hussien (2010) and Hussein (2011) reported that the highest sugar beet root yield was recorded by application of potassium bicarbonate.

Data illustrated in Table (4) show that all control materials significantly increased sucrose (\%) compared with the untreated control. Score treatment showed the highest increase where sucrose $(\%)$ recorded $17.23 \%$ followed by Bio ARC $16.75 \%$ then Salicylic acid $16.45 \%$ while Zink sulphate showed the lowest increase where sucrose $(\%)$ recorded $13.93 \%$. Other treatments, i.e. Boric acid gave $14.56 \%$ and Blite stop $15.12 \%$. Spraying at 60,90and 120 days after planting achieved the highest increase where sucrose (\%) recorded $15.82 \%$ while spraying at 90 and 120 days gave the lowest increase where sucrose (\%) recorded $14.79 \%$. With respect to locations, New Nubariya was the best where sucrose (\%) recorded $15.46 \%$ compared with Kafr El-Sheikh which recorded $15.33 \%$. It is worth mentioning that the correlation between disease severity and sucrose (\%) was high negative which recorded (-0.789).

Table (3): Effect of spraying the control materials on rootyield (ton/fed) of sugar beet under field conditions at two locations.

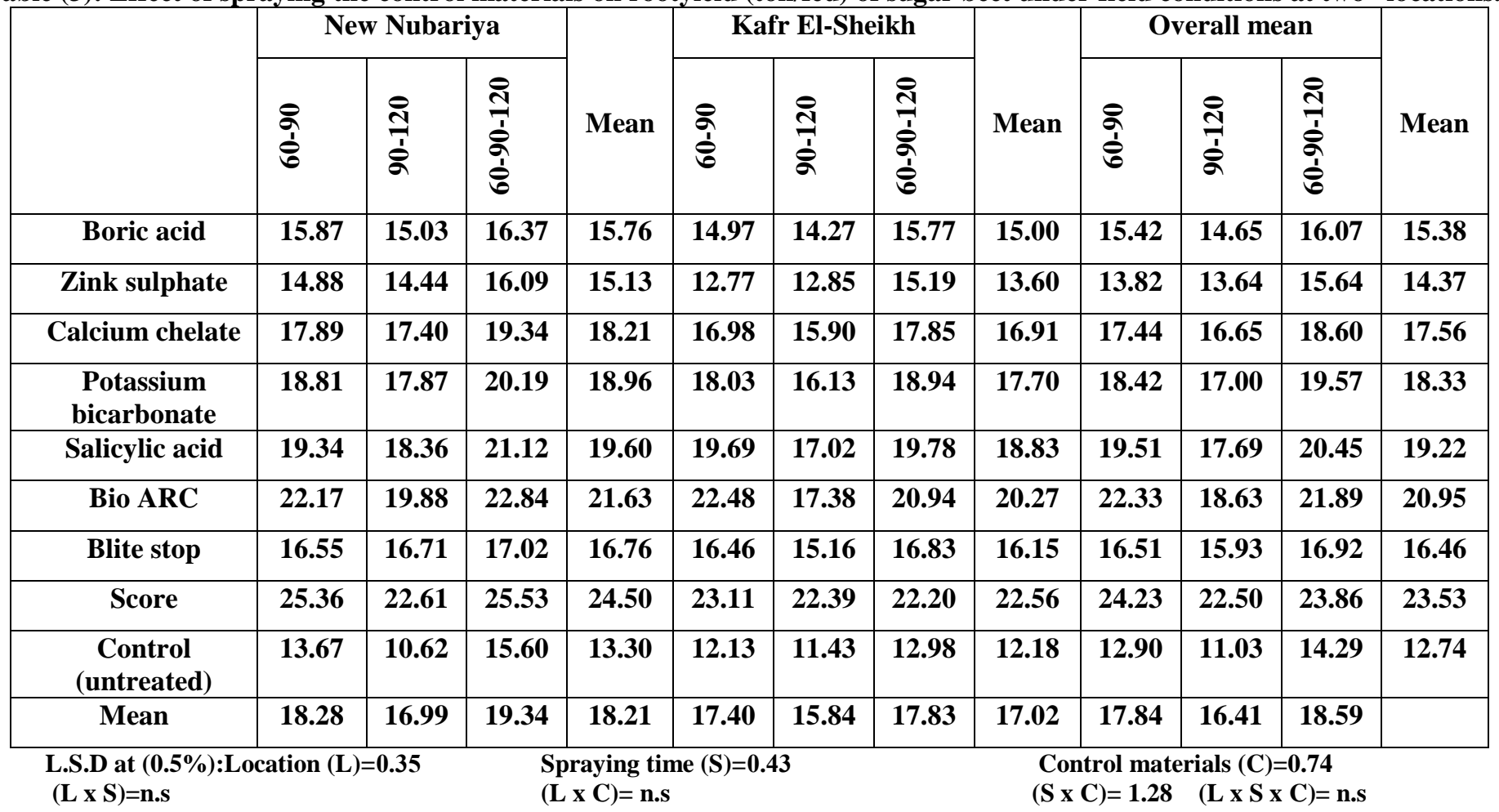


Hussienl (2010) and Hussein (2011) reported that the highest sugar beet sucrose percentage was recorded by application of potassium bicarbonate.

The data illustrated in Table (5) show that all control materials significantly increased the sugar yield compared with the untreated control. Score treatment showed the highest increase where sugar yield recorded 4.05 ton/fed followed by Bio-ARC

Table (4): Effect of spraying control materials on sucrose (\%) of sugar beet grown under field conditions at two locations.

\begin{tabular}{|c|c|c|c|c|c|c|c|c|c|c|c|c|}
\hline & \multicolumn{3}{|c|}{ Nubariya } & \multirow[b]{2}{*}{ Mean } & \multicolumn{3}{|c|}{ Kafr-El-Sheikh } & \multirow[b]{2}{*}{ Mean } & \multicolumn{3}{|c|}{ Overall mean } & \multirow[b]{2}{*}{ Mean } \\
\hline & 옹 & $\frac{\text { ิ }}{\text { ฉ̊ }}$ & 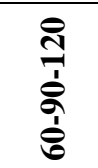 & & ริ & 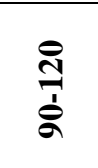 & 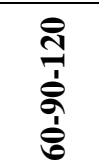 & & \&ิ & $\frac{\text { \ิ }}{\text { \&̊ }}$ & 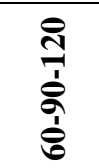 & \\
\hline Boric acid & 15.20 & 13.37 & 15.50 & 14.69 & 15.03 & 13.17 & 15.07 & 14.42 & 15.12 & 13.27 & 15.28 & 14.56 \\
\hline Zink sulphate & 14.80 & 12.93 & 15.00 & 14.24 & 12.97 & 12.90 & 14.97 & 13.61 & 13.88 & 12.92 & 14.98 & 13.93 \\
\hline Calcium chelate & 15.93 & 14.90 & 16.13 & 15.66 & 16.00 & 15.47 & 15.60 & 15.69 & 15.97 & 15.18 & 15.87 & 15.67 \\
\hline $\begin{array}{c}\text { Potassium } \\
\text { bicarbonate }\end{array}$ & 16.10 & 15.57 & 16.73 & 16.13 & 16.57 & 15.50 & 16.13 & 16.07 & 16.33 & 15.53 & 16.43 & 16.10 \\
\hline Salicylic acid & 16.53 & 15.87 & 16.93 & 16.44 & 16.83 & 16.10 & 16.43 & 16.46 & 16.68 & 15.98 & 16.68 & 16.45 \\
\hline Bio ARC & 16.67 & 16.53 & 17.30 & 16.83 & 16.90 & 16.53 & 16.57 & 16.67 & 16.78 & 16.53 & 16.93 & 16.75 \\
\hline Blite stop & 15.47 & 13.87 & 15.77 & 15.03 & 15.73 & 14.60 & 15.27 & 15.20 & 15.60 & 14.23 & 15.52 & 15.12 \\
\hline Score & 17.07 & 17.07 & 17.68 & 17.27 & 17.27 & 17.43 & 16.87 & 17.19 & 17.17 & 17.25 & 17.27 & 17.23 \\
\hline $\begin{array}{c}\text { Control } \\
\text { (untreated) }\end{array}$ & 13.13 & 12.33 & 13.07 & 12.84 & 12.27 & 12.17 & 13.70 & 12.71 & 12.70 & 12.25 & 13.38 & 12.78 \\
\hline Mean & 15.66 & 14.71 & 16.01 & 15.46 & 15.51 & 14.87 & 15.62 & 15.33 & 15.58 & 14.79 & 15.82 & \\
\hline
\end{tabular}

Table (5): Effect of spraying some control materials on sugaryield (ton/fed) of sugar beet under field conditions at two locations.

\begin{tabular}{|c|c|c|c|c|c|c|c|c|c|c|c|c|}
\hline & \multicolumn{3}{|c|}{ New Nubariya } & \multirow[b]{2}{*}{ Mean } & \multicolumn{3}{|c|}{ Kafr El-Sheikh } & \multirow[b]{2}{*}{ Mean } & \multicolumn{3}{|c|}{ Overall mean } & \multirow[b]{2}{*}{ Mean } \\
\hline & हి & $\frac{\text { ิ }}{\text { §ิ }}$ & 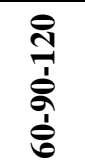 & & $\begin{array}{l}\text { ì } \\
\text { है }\end{array}$ & $\frac{\text { đิ }}{\text { §̆ }}$ & 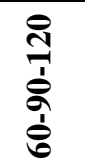 & & $\begin{array}{l}8 \\
\text { î̀ }\end{array}$ & 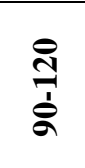 & 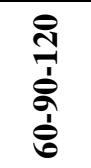 & \\
\hline Boric acid & 2.37 & 1.98 & 2.47 & 2.27 & 2.28 & 1.91 & 2.44 & 2.21 & 2.32 & 1.94 & 2.45 & 2.24 \\
\hline Zink sulphate & 1.93 & 1.86 & 2.41 & 2.07 & 1.89 & 1.66 & 2.27 & 1.94 & 1.91 & 1.76 & 2.34 & 2.00 \\
\hline Calcium chelate & 2.87 & 2.69 & 3.02 & 2.86 & 2.70 & 2.37 & 2.89 & 2.65 & 2.78 & 2.53 & 2.95 & 2.75 \\
\hline Potassium bicarbonate & 3.12 & 2.76 & 3.26 & 3.05 & 2.90 & 2.51 & 3.17 & 2.86 & 3.01 & 2.64 & 3.22 & 2.95 \\
\hline Salicylic acid & 3.26 & 2.94 & 3.48 & 3.22 & 3.26 & 2.70 & 3.35 & 3.10 & 3.26 & 2.82 & 3.41 & 3.16 \\
\hline Bio ARC & 3.76 & 3.27 & 3.79 & 3.60 & 3.75 & 2.87 & 3.62 & 3.41 & 3.75 & 3.07 & 3.71 & 3.51 \\
\hline Blite stop & 2.60 & 2.44 & 2.60 & 2.55 & 2.54 & 2.10 & 2.65 & 2.43 & 2.57 & 2.27 & 2.62 & 2.49 \\
\hline Score & 4.38 & 3.94 & 4.31 & 4.21 & 3.94 & 3.82 & 3.93 & 3.90 & 4.16 & 3.88 & 4.12 & 4.05 \\
\hline $\begin{array}{c}\text { Control } \\
\text { (untreated) }\end{array}$ & 1.68 & 1.27 & 2.13 & 1.69 & 1.59 & 1.41 & 1.70 & 1.57 & 1.63 & 1.34 & 1.91 & 1.63 \\
\hline Mean & 2.88 & 2.57 & 3.05 & 2.84 & 2.76 & 2.37 & 2.89 & 2.68 & 2.82 & 2.47 & 2.97 & \\
\hline
\end{tabular}


3.51 ton/fed, then Salicylic acid 3.16 ton/fed while Zink sulphate gave the lowest increase where sugar yield recorded 2 ton/fed. Other treatments, i.e. Boric acid recorded 2.24 ton/fed and Blite stop 2.49 ton/fed. Spraying at 60,90 and 120 days after planting achieved the highest increase where sugar yield recorded 2.97 ton/fed while spraying at 90 and 120 days gave the lowest increase where sugar yield recorded 2.47 ton/fed. In respect to locations, New Nubariya showed the best, where sugar yield recorded 2.84 ton/fed compared with Kafr ElSheikh which recorded 2.68 ton/fed. It is worth mentioning that the correlation between disease severity and sugar yield was high negative which recorded (-0.714). In the same respect, Kristek et al. (2007) reported that the highest value of sugar yield was obtained by inoculation sugar beet roots with Pseudomonas fluorescens. Also, Soudi and El- Guibali (2008) reported that application of $\mathrm{Zn}$ increased yield and quality of sugar beet.

The data illustrated in Table (6) show that the tested control materials significantly increased phenol contents compared with the untreated control. Salicylic acid treatment showed the highest increase where free phenols recorded $92.15 \mathrm{mg} / \mathrm{g}$ fresh weight, conjugated phenols recorded $102.81 \mathrm{mg} / \mathrm{g}$ fresh weight and total phenols recorded $194.96 \mathrm{mg} / \mathrm{g}$ fresh weight followed by Potassium bicarbonate where free phenols recorded $84.17 \mathrm{mg} / \mathrm{g}$ fresh weight, conjugated phenols recorded $99.57 \mathrm{mg} / \mathrm{g}$ fresh weight and total phenols recorded $183.74 \mathrm{mg} / \mathrm{g}$ fresh weight, then Calcium chelate where free phenols recorded $74.81 \mathrm{mg} / \mathrm{g}$ fresh weight, conjugated phenols recorded $96.38 \mathrm{mg} / \mathrm{g}$ fresh weight and total phenols recorded $171.19 \mathrm{mg} / \mathrm{g}$ fresh weight while zink sulphate caused the lowest increase where free phenols recorded $36.72 \mathrm{mg} / \mathrm{g}$ fresh weight, conjugated phenols recorded 80.65 $\mathrm{mg} / \mathrm{g}$ fresh weight and total phenols recorded $117.38 \mathrm{mg} / \mathrm{g}$ fresh weight. Other treatments such as Boric acid gave free phenols $44.04 \mathrm{mg} / \mathrm{g}$ fresh weight, conjugated phenols recorded 87.63 $\mathrm{mg} / \mathrm{g}$ fresh weight and total phenols $131.67 \mathrm{mg} / \mathrm{g}$ fresh weight, and Blite stop where free phenols recorded $54.6 \mathrm{mg} / \mathrm{g}$ fresh weight, conjugated phenols $91.07 \mathrm{mg} / \mathrm{g}$ fresh weight and total phenols (145.68 $\mathrm{mg} / \mathrm{g}$ fresh weight). In respect to locations, New Nubariya showed the highest values for conjugated phenols, being $92.79 \mathrm{mg} / \mathrm{g}$ fresh weight and total phenols $150.83 \mathrm{mg} / \mathrm{g}$ fresh weight compared to Kafr El-Sheikh where conjugated phenols recorded $85.72 \mathrm{mg} / \mathrm{g}$ fresh weight and total phenols recorded $148.15 \mathrm{mg} / \mathrm{g}$ fresh weight while Kafr El-Sheikh was the best for free phenols, being $62.43 \mathrm{mg} / \mathrm{g}$ fresh weight compared with New Nubariya free phenols recorded $58.04 \mathrm{mg} / \mathrm{g}$ fresh weight. It is worth mentioning that the correlation between disease severity and free phenols was medium negative which recorded (-0.586), the correlation between disease severity and conjugated phenols was high negative which recorded (-0.714) and the correlation between disease severity and total phenols was high negative which recorded (0.706). In the same respect, Hammerschmidt and Smith-Becker (1999) reported that Salicylic acid (SA) is a phenolic compound that affects a variety of biochemical and molecular events associated with induction of disease resistance. Salicylic acid has been shown to play an important role in expression of both local resistance controlled by major genes and systemic induced resistance developed after an initial pathogen attack. Also, Hussien (2010) and Hussein (2011) reported that all phenols free, conjugated and total were higher in plants treated by potassium bicarbonate. In regards to of boron action in reducing disease susceptibility, Brown et al. (2002)) showed its role in metabolism of phenolics or lignin.

The data illustrated in Table (7) show that the tested control materials significantly increased Polyphenoloxidase and peroxidase activity compared to the untreated control. Salicylic acid treatment caused the highest increase where polyphenoloxidase recorded 0.562 and peroxidase recorded 0.974 followed by Potassium bicarbonate where polyphenoloxidase recorded 0.510 and peroxidase recorded 0.843 while Bio ARC treatment caused the lowest increase where polyphenoloxidase recorded 0.331 and peroxidase recorded 0.615 followed by calcium chelate polyphenoloxidase recorded 0.435 and peroxidase recorded 0.763 . With respect to locations, New Nubariya was the best where peroxidase recorded 0.785 compared with Kafr El-Sheikh where it recorded 0.765 while Kafr El-Sheikh was the best in polyphenoloxidase which recorded 0.443 compared with New Nubariya which recorded 0.440 . It is worth mentioning that the correlation 
Table (6): Effect of some control materials on phenol contents (free, conjugated and total phenols) ( $\mathrm{mg} / \mathrm{g}$ fresh weight) in sugar beet under field conditions at two locations.

\begin{tabular}{|c|c|c|c|c|c|c|c|c|c|}
\hline & \multicolumn{3}{|c|}{ Nubariya } & \multicolumn{3}{|c|}{ Kafr El-Sheikh } & \multicolumn{3}{|c|}{ Overall mean } \\
\hline & 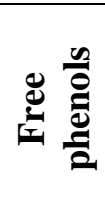 & 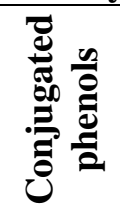 & $\begin{array}{l}\frac{n}{0} \\
\stackrel{\tilde{0}}{0} \\
\stackrel{0}{0}\end{array}$ & 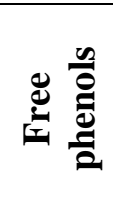 & 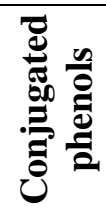 & $\begin{array}{l}\frac{0}{0} \\
\frac{\pi}{0} \\
\stackrel{0}{0}\end{array}$ & 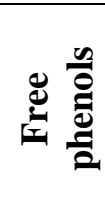 & 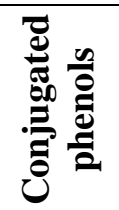 & 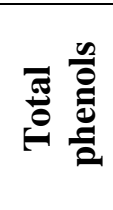 \\
\hline Boric acid & 43.64 & 88.29 & 131.93 & 44.44 & 86.97 & 131.41 & 44.04 & 87.63 & 131.67 \\
\hline Zink sulphate & 36.06 & 78.42 & 114.48 & $\mathbf{3 7 . 3 8}$ & 82.89 & 120.27 & 36.72 & 80.65 & 117.38 \\
\hline Calcium chelate & 72.23 & 101.09 & 173.32 & 77.39 & 91.68 & 169.07 & 74.81 & 96.38 & $\mathbf{1 7 1 . 1 9}$ \\
\hline Potassium bicarbonate & 81.24 & 105.34 & 186.58 & 87.09 & 93.80 & 180.89 & 84.17 & 99.57 & 183.74 \\
\hline Salicylic acid & 90.83 & $\mathbf{1 0 8 . 5 0}$ & 199.32 & 93.47 & 97.13 & 190.60 & 92.15 & 102.81 & 194.96 \\
\hline Bio ARC & 62.75 & 100.92 & 163.67 & 69.07 & 86.28 & 155.35 & 65.91 & 93.60 & 159.51 \\
\hline Blite stop & 50.18 & 95.58 & 145.76 & 59.02 & 86.57 & 145.59 & 54.60 & 91.07 & 145.68 \\
\hline $\begin{array}{c}\text { Contro } \\
\text { (untreated) }\end{array}$ & 27.39 & 64.18 & 91.57 & 31.58 & 60.45 & 92.03 & 29.49 & 62.31 & 91.80 \\
\hline Mean & 58.04 & 92.79 & 150.83 & 62.43 & 85.72 & 148.15 & & & \\
\hline
\end{tabular}

L.S.D at $(0.5 \%)$ :

$\begin{array}{llll}\text { Locations }(L)= & \text { n.s } & \text { n.s } & \text { n.s } \\ \text { Cont.materials. }(C)= & 6.11 & 5.93 & 6.58 \\ (\text { L x C })= & \text { n.s } & \text { n.s } & \text { n.s }\end{array}$

Table (7): Effect of some control materials (chemicals, biocides) on polyphenoloxidase and peroxidase (optical density/minute /gram fresh weight) of sugar beet plants grown under natural infection with Cercospora beticola under field conditions at two locations.

\begin{tabular}{|c|c|c|c|c|c|c|}
\hline & \multicolumn{2}{|c|}{ Nubariya } & \multicolumn{2}{c|}{ Kafr El-Sheikh } & \multicolumn{2}{c|}{ Overall mean } \\
\cline { 2 - 7 } & $\begin{array}{c}\text { Polyphenol } \\
\text { oxidase }\end{array}$ & Peroxidase & $\begin{array}{c}\text { Polyphenol } \\
\text { oxidase }\end{array}$ & Peroxidase & $\begin{array}{c}\text { Polyphenol } \\
\text { oxidase }\end{array}$ & Peroxidase \\
\hline Calcium chelate & $\mathbf{0 . 4 3 5}$ & $\mathbf{0 . 7 6 3}$ & $\mathbf{0 . 4 5 9}$ & $\mathbf{0 . 7 4 8}$ & $\mathbf{0 . 4 4 7}$ & $\mathbf{0 . 7 5 5}$ \\
\hline Potassium bicarbonate & $\mathbf{0 . 5 1 0}$ & $\mathbf{0 . 8 4 3}$ & $\mathbf{0 . 5 1 0}$ & $\mathbf{0 . 8 1 8}$ & $\mathbf{0 . 5 1 0}$ & $\mathbf{0 . 8 3 0}$ \\
\hline Salicylic acid & $\mathbf{0 . 5 6 2}$ & $\mathbf{0 . 9 7 4}$ & $\mathbf{0 . 5 6 0}$ & $\mathbf{0 . 9 4 8}$ & $\mathbf{0 . 5 6 1}$ & $\mathbf{0 . 9 6 1}$ \\
\hline Bio ARC & $\mathbf{0 . 3 6 2}$ & $\mathbf{0 . 7 3 0}$ & $\mathbf{0 . 3 6 8}$ & $\mathbf{0 . 6 9 8}$ & $\mathbf{0 . 3 6 5}$ & $\mathbf{0 . 7 1 4}$ \\
\hline Control (untreared) & $\mathbf{0 . 3 3 1}$ & $\mathbf{0 . 6 1 5}$ & $\mathbf{0 . 3 1 7}$ & $\mathbf{0 . 6 1 6}$ & $\mathbf{0 . 3 2 4}$ & $\mathbf{0 . 6 1 5}$ \\
\hline Mean & $\mathbf{0 . 4 4 0}$ & $\mathbf{0 . 7 8 5}$ & $\mathbf{0 . 4 4 3}$ & $\mathbf{0 . 7 6 5}$ & & \\
\hline
\end{tabular}

L.S.D at $(0.5 \%)$ :

Locations $(\mathrm{L})=\quad$ n.s $\quad 0.011$

Cont.materials $(C)=\quad 0.039 \quad 0.024$

$(\mathbf{L} \times \mathbf{C})=\quad$ n.s $\quad$ n.s 
between disease severity and Polyphenoloxidase was medium negative which recorded $(-0.554)$ and the correlation between disease severity and Peroxidase was medium negative which recorded $(-0.574)$. These results are in agreement with the findings of Mahmoud et al. (2006) who found a significant increase in the total peroxidase activity in peanut plants treated with Salicylic acid; Daw et al. (2008) recorded an increase of peroxidase activity after rice foliar spray with $8 \mathrm{mM}$ SA. Kamal et al. (2009) stated that onion plants treated by SA and inoculated with the pathogen exhibited higher peroxidase, polyphenoloxidase activities and phenolic content at all time intervals than inoculated water-treated plants. Thus, application of SA on onion plants led to significant reduction in disease severity compared to the control plants. Also, Ibrahim et al. (2013) found an increase of oxidative enzymes activity and content of phenol compounds after peanut leaf treated with Salicylic acid. Hammerschmidt and Smith-Becker (2000) reported that among the most commonly chemical elicitors, Salicylic acid has been shown to play an important role in expression of both local resistance, controlled by major genes, and systemic induced resistance developed after an initial pathogen attack. Thanh et al. (2017) reported that foliar sprays with Salicylic acid (SA) provided an increase production of $\mathrm{O}_{2}^{-}$. The $\mathrm{O}_{2}{ }^{-}$ not only has direct toxicity to pathogens, but it is also the central component of the plant defence signal transduction pathways. Also, they observed enhancement of polyphenoloxidase activity and production of plant phytoalexins.

In general, New Nubariya plants were the best, as they showed disease tolerance, root yield and sugar yield more than Kafr El-Sheikh plants. This may be due to different soil types in the two locations.

\section{REFERENCES}

Abdel-Al A. E., Abd-El-Kader D. A., Khder M. A. and Khalifa M.M. (2012). Induction of resistance in sesame plants against charcoal rot diseases by some chemical inducers. Zagazig J. Agric. Res., 39(2):189-202.

Allam A.I. and Hollis S.P. (1972). Sulfide inhibition of oxidase in rice root. Phytopathology. 62: 634-636.
Awad K. I. (2005). Studies on some virus diseases in sugar beet plants. Ph.D. Thesis, Fac. Agric., El-Azhar, Univ., Cairo, Egypt.

Banerjee J., Das N., Dey P. and Maiti M. (2010). Transgenically expressed rice germin-like protein 1 in tobacco causes hyperaccumulation of $\mathrm{H}_{2}{ }_{2}$ and reinforcement of the cell wall components. Biochem. Biophys. Res. Commun., 402:637-643.

Blevins D. and Lukaszewski K. (1998). Boron in plant structure and function, Annu. Rev. Plant Phys., 49: 481-500.

Bloom B., Ehlers R., Salinas S., Hoddanen H. and Jung K. (2003). Biological control agents: Safety and regulatory policy. BioControl, 48: 477-484.

Bray H. G. and Thrope W. V. (1954). Analysis of phenolic compounds of interest. Metabol. Methods Chem. Analysis, 1:27-51.

Brown P.H., Bellaloui N., Wimmer M.A., Bassil E. S., Ruiz J., Hu H., Pfeffer H., Dannel F and Romheld V. (2002). Boron in plant biology. Plant Biol., 4: 205-223.

Cakmak I. (2000). Possible roles of zinc in protecting plant cells from damage by reactive oxygen species. New Phytol., 146: 185-205.

Conway W.S., Sams C.E., Mcguire R.G. and Kelman A. (1992). Calcium treatment of apples and potatoes to reduce post-harvest decay. Plant Dis., 76:329-334.

Daw B.D., Zhang L.H. and Wang Z.Z. (2008). Salicylic acid enhances antifungal resistance to Magnaporthe grisea in rice plants. Aust. Plant Path., 37:637-644.

Dexter S.T., Frankes M.G. and Snyder F.W. (1967). A rapid and practical method of determining extractable white sugar as may be applied to the evaluation of economic practices and grower deliveries in the sugarbeet industry. J. Am., Soc., Sugar Beet Technol., 14: 433-454.

EI-Kholi M.A. and Esh A.M. (2011). Comparative structural and biochemical study on calcium effects on Cercospora leaf spot disease of sugar beet. J. Plant Prot. Path., Mansoura Univ., 2 (1):85-97.

El-Assiuty E.M., Rizk M.A. and Ibrahim A.E. (2009). Antimicrobial activity of sugar beet phyllospheric microorganisms against 
Cercospora beticola Sacc. Egypt J. Agric. Res., 87 (4): 879-890.

El-Sayed A.B. and El-Sherbeni S.A. (2017). Efficacy of Cassia nodosa extracts in the management of Cercospora leaf spot of sugar beet caused by Cercospora beticola. Chem. Res. J., 2 (4):158-170.

Eweis M., El-Kholy S.S. and El-Sabee M.Z. (2006). Antifungal efficacy of chitosan and its thiourea derivatives upon the growth of some sugar beet pathogens. Int'l. J. Biol. Macromol., 38:1-8.

Felipini R.B., Luiz C., Costa M.E. and Piero R. M. (2015). Mode of action of chitosan and ASM for the control of Cercospora leaf spot on table beet. Tropic. Plant Pathol., 40 (3):176-183.

Galletti S., Burzi P.L., Cerato C., Marinello S and Sala E. (2008). Trichoderma as a potential biocontrol agent for Cercospora leaf spot of sugar beet. Biocontrol, 53(6): 917-930.

Ganesan V and Thomas G. (2001). Salicylic acid response in rice: influence of salicylic acid on $\mathrm{H} 2 \mathrm{O} 2$ accumulation and oxidative stress. Plant Sci., 160:1095-1106.

Goldschmidt E. E., Goren R. and Wood S. P. (1968). Photosynthesis. pages 46-74 in: The Biochemistry and Physiology of Plant Disease. Univ. of Missouri Press, Columbia,USA. 433pp.

Hammerschmidt R and Smith-Becker J.A. (1999). The role of salicylic acid in disease resistance. In: Agrawal, A.A.; Tuzun, S.; Bent, E., (eds). Induced Plant Defenses Against Pathogens and Herbivores. APS Press St. Paul, MN, USA. pp 37-53.

Hammerschmidt R. and Smith-Becker J.A. (2000). The Role of Salicylic Acid in Disease Resistance. In Mechanisms of Resistance to Plant Diseases. (Eds: Slusarenko, A., Fraser,R. S. S., Van Loon, L. C.), pp. 3753, Kluwer Academic Publisher.

Hussien Manal Y. (2006). Induced resistance of sugar beet plant against leaf spot disease caused by Cercospora beticola Sacc. Minufiya J. Agric. Res., 31 (1): 9-20.

Hussien Manal Y. (2010). Efficacy of some bicarbonate salts in controlling sugar beet leaf spot disease caused by Cercospora beticola (Sacc). Egypt. J. Appl. Sci., 25 (8A): 269-282.

Hussien Manal Y., Abd El-All A.A.M and Mostafa S.S. (2009). Bioactivity of algal extracellular by products on Cercospora leaf spot disease, growth performance and quality of sugar beet. The $4^{\text {th }}$ Conf. Recent Technologies in Agriculture, Proceedings, 3-5 Nov., 1, 119-129, Plant Protection, Cairo Univ., Egypt.

Hussein Z.N. (2011). New approaches for controlling peanut root and pod rots diseases caused by Rhizoctonia solani. Ph.D. Thesis, Inst. of African Res. and Studies, Cairo Univ., Egypt 80 pp.

Ibrahim M.M., Khalifa M.M. and Mahmoud E.Y. (2013). Using of chemical inducers on control peanut Cercospora leaf spot as one of the possible alternative to fungicides. Egypt. J. Appl. Sci., 28(7): 268-285.

Jung H.K and Kim S.D. (2005). An antifungal antibiotic purified from Bacillus megaterium KL39, a biocontrol agent of red-pepper Phytophthora-blight disease. J. Microbiol. Biotechnol., 15 (5): 1001-1010.

Kaiser U and Varrelmann M. (2009). Development of a field biotest using artificial inoculation to evaluate resistance and yield effects in sugar beet cultivars against Cercospora beticola. Eur. J. Plant Pathol., 124:269- 281.

Kamal A. M., Hussein M. A. M., Allam A.D and Hassan M. H. (2009). Salicylic acid induced systemic resistance on onion plants against Stemphylium vesicarium. Arch. Phytopatho. Plant Protect., 42(11):1042-1050.

Kildea S., Ransbotyn V., Khan M., Fagan B., Leonard G., Mullins E and Doohan F. (2008). Bacillus megaterium shows potential for the biocontrol of Septoria tritici (blotch of wheat). Biol. Cont., 47: 3745.

Kristek S., Kristek A., Pospisil M., Tokic R. and Cosic J. (2007). Influence of bacterium Pseudomonas fluorescens on the pathogen of root rot, Rhizoctonia solani, storage period and elements of sugar beet yield and quality. Zuckerindustrie (Sugar industry), 132 (7):568-575.

Kumar V., Reddy M., Kloepper J., Yellareddygari S., Lawrence K., Zhou X., Sudini H., Miller 
M., Podile A and Reddy S. (2011). Plant growth-promoting activities of Bacillus subtilis MBI 600 (Integral $\AA$ ) and its compatibility with commonly used fungicides in rice sheath blight management. Int'l. J. Microbiol. Res., 3:120-130.

Le-Docte A. (1927). Commercial determination of sugar in the beet root using the Sachs-Le Docte process. Int'l. Sugar. J., 29: 488-492.

Li X. and Zhang L. (2012). SA and PEG-induced priming for water stress tolerance in rice seedling. Inf. Tech. Agric. Eng., 134:881887.

Mahmoud E.Y, Shokry S.Y and Hussin Z. N. (2006). Induction of resistance in peanut plants against root rot diseases under greenhouse conditions by some chemical inducers. J. Agric. Sci. Mansoura Univ., 31(6):3511-3524.

Malta A and Dimond A. (1963). Symptoms of Fusarium wilt tomato stems. Phytopathology, 53: 574-587.

Mandal S., Mallicka N. and Mitraa A. (2009). Salicylic acid induced resistance to Fusarium oxysporum f. sp. lycopersici in Tomato. Plant Physiolo. Bioch., 47 (7):642-649.

Shafi J., Tian H. and Ji M. (2017). Bacillus species as versatile weapons for plant pathogens: a review. Biotech. Biotechnolo. Equip., 31(3):446-459.
Shane W.W and Teng P.S. (1992). Impact of Cercospora leaf spot on root weight, sugar yield, and purity of Beta vulgaris. Plant Dis., 76 (8):812-820.

Simlanick J.L., Mansour M.F and Sorenson D. (2006). Pre- and post- harvest treatments to control green mould of citrus fruit during ethylene degreasing. Plant Dis., 90:89-96.

Soudi A.K and El-Guibali A. H. (2008). Effect of foliar application with some micronutrients on yield and quality of sugar beet. Egypt. J. Appl. Sci., 23(3): 41-51.

Snedecor G.W and Cochran W.G. (1981). Statistical Methods. Seventh Ed. Iowa State Univ. Press, Ames., Iowa, USA.

Takatsuji H. (2014). Development of diseaseresistant rice using regulatory components of induced disease resistance. Front. Plant Sci., 5:1-12.

Thanh T. L., Thumanu K., Wongkaew S., BoonkerdN., Teaumroong N., Phansak P. and Buensanteai N. (2017). Salicylic acidinduced accumulation of biochemical components associated with resistance against Xanthomonas oryzae pv. oryzae in rice. J. Plant Interactions, 12 (1): 108-120.

Xing T., Higgins $\mathrm{J}$ and Blumwald E. (1996). Regulation of plant defense response to fungal pathogens: two types of protein kinases in the reversible phosphorylation of the host plasma membrane $\mathrm{H}^{+}$-ATPase. The plant cell, 8: 555-564.

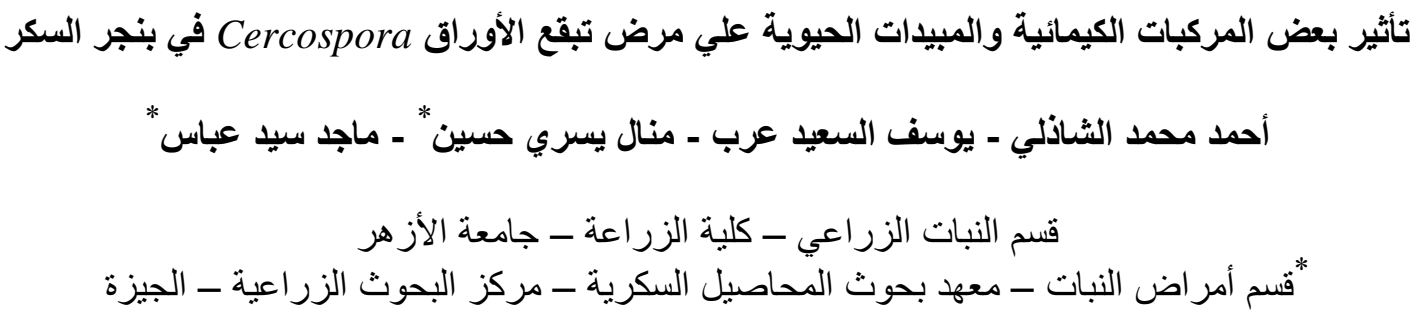

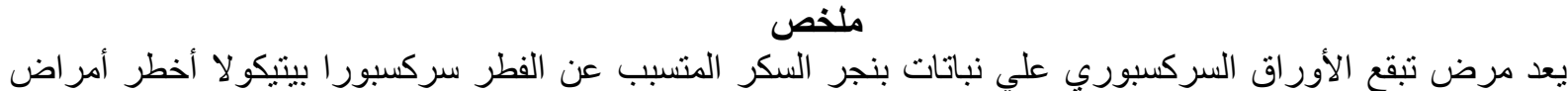

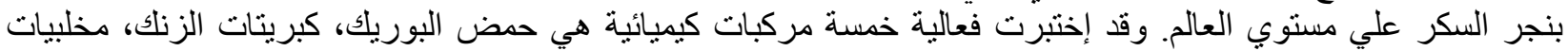

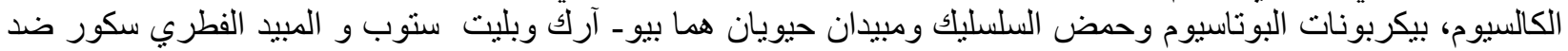

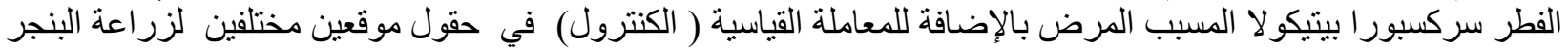




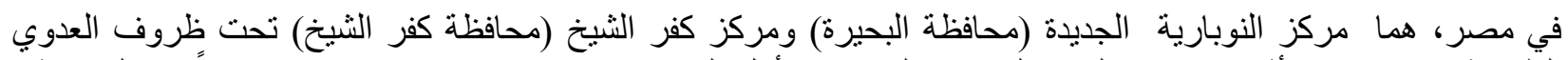

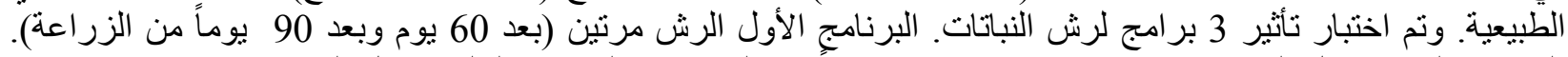

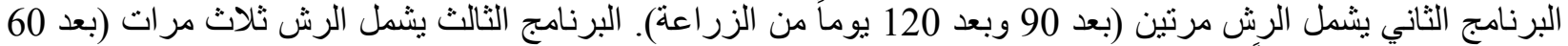

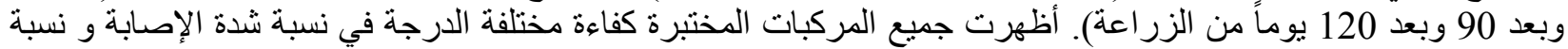

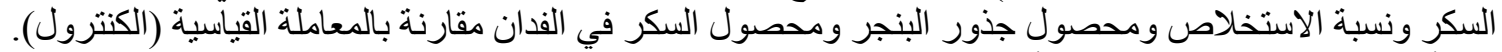

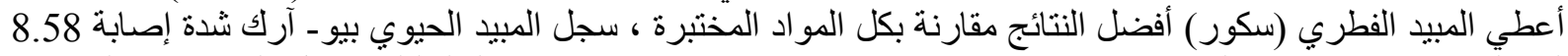
\% يليه بليث - سوب (مبيد الحيوي مصري تجاري جديد) 12.27 \%. كان حمض السلسليك افضل المستخثنات الكيماوية

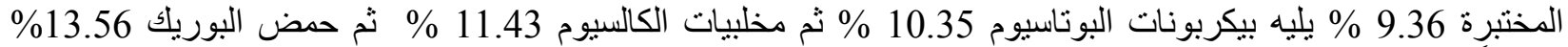

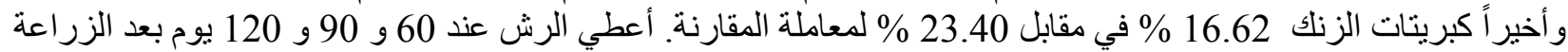

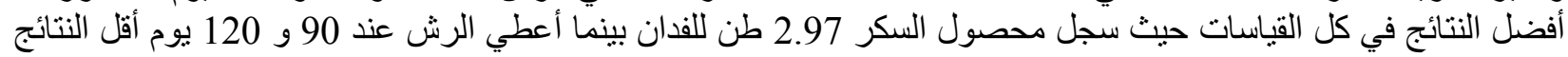
2.97 طن للفدان.

كانت نباتات النوبارية الجديدة الأفضل في تحمل المرض و و محصول الجذور و محصو محصول السكر بينما لم تتأثر نسبة

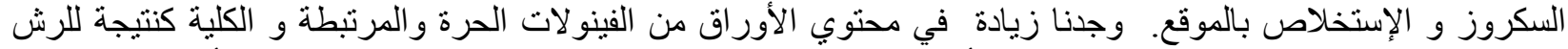

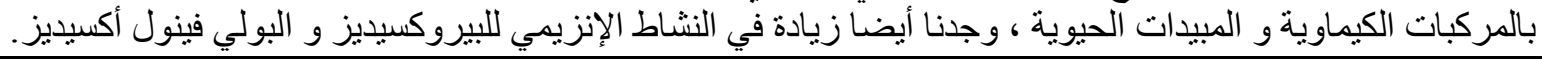
المجلة العلمية ـ كلية الزراعة جامعة القاهرةـ المجلد ( 69) العدد الثالث (يوليو 2018)211-222. 